\title{
The Effects of Indonesian Macroeconomic Indicators and Global Stock Price Index on the Composite Stock Prices Index in Indonesia
}

\author{
I Nengah Aryasta Luh Gede Sri Artini \\ Department of Financial Management, Faculty of Economics and Business, Udayana University, Denpasar, Bali, \\ Indonesia
}

\begin{abstract}
This study was to analyze the effect of Gross Domestic Product (GDP), the rupiah exchange rate against the US dollar, inflation, interest rates, Dow Jones Index, BSE Sensex Index, Nikkei-225 Index, and Shanghai Index on the composite stock prices index in Indonesia. The study used secondary data obtained from www.yahoo.finance.com, Central Bank of Indonesia, and the Indonesian Central Bureau of Statistics. Data was collected in the quarter period from January 2010 - December 2018 with 36 data numbers per each variable. Multiple linear regression analysis technique was used for the analytical method. The results showed GDP, exchange rates, the Shanghai index had a significant positive effect, the Nikkei-225 index had a significant negative effect to the JCI. Inflation, interest rates, and the BSE Sensex index had insignificant negative effect to the JCI. The variables that were worthy of consideration for investors in purchasing shares on the Indonesia Stock Exchange were GDP, the rupiah exchange rate against the US dollar, the Dow Jones index, the Nikkei-225 index, and the Shanghai index because it significantly affects the JCI. The suggestion for further research was to include other economic variables such as the money supply, unemployment rate, and stock indices of developing countries.
\end{abstract}

Keywords: Indonesian Macro Economic Indicators, Global Stock Index, Indonesian composite of stock price index

DOI: $10.7176 /$ IKM/9-9-03

Publication date:October $31^{\text {st }} 2019$

\section{Introduction}

Investment is an activity to place funds both in financial and non-financial instruments to obtain an increase in investment value (Balagobei, 2017). Stock is one form of investment in the capital market that provides two benefits, namely capital gains and dividends (Khajar, 2015). The movement of shares in the capital market can be seen from the stock index. The stock index fluctuates in accordance with internal and external conditions of a country. External influences are caused more by global factors due to globalization especially in the field of trade and international economic cooperation. Fundamental analysis is needed to forecast stock performance before investors engage in investment activities (Baresa et al., 2013). Stock valuation analysis must be considered several macroeconomic variables that affect a company's ability to generate profits (Tandelilin, 2010). There are three stages in fundamental analysis, namely the analysis of macroeconomic factors that affect the performance of the entire company, followed by industry analysis, and company analysis to find out whether the securities issued are profitable or detrimental (Tandelilin, 2010).

The research was conducted by Chia Liang et al (2013) showed a positive short-term and long-term relationship between exchange rates (US Dollars) and stock prices in five ASEAN countries. The significant influence of the macro economy on the stock index is largely determined by the fundamental conditions of the country and the relationship of one country to another. Comprehensive research related to the influence of macroeconomic variables on the index of composite stock prices in Malaysia, America and China have been carried out by Acikalin et al (2008); Geetha et al (2011); Chia Liang et al (2013); Duy (2015); Balagobei, (2017). The results of the study indicate that macroeconomic indicators such as inflation and interest rates negatively affect stock prices, while the exchange rate and GDP have a positive effect on stock prices. Fluctuations due to external conditions occur because of liberalization process in investment. Investment liberalization implies an increasingly connected Indonesian capital market with foreign capital markets, both regionally and globally (Tarigan et al., 2015). The liberalization process occurs because of the existence of trade and economic cooperation relations between countries that influence each other in accordance with the proportion of economic dependence. The dynamic condition of the capital market is one of the main indicators of economic changes in the world as reflected in the index of share prices of each country. The movement of index value is one of the factors that can be used in analyzing the level of capital market integration between countries (Tarigan et al., 2015).

Based on the background and previous research that there are differences of opinion among researcher is interested to further analyze the "The Effects of Indonesian Macroeconomic Indicators and Global Stock Price 
Index on the Composite Stock Prices Index in Indonesia".

\section{Literature Riview and Hypothesis \\ 2.1 Investation}

Investment is one component of aggregate expenditure, so an increase in investment will increase aggregate demand, national income and employment opportunities. Investment can be divided into two, namely investment in financial assets and investment in real assets (Wiksuana, 2017). Stock is one of the financial market instruments carried out in the capital market (Mark, 2017). The goal is to get a return on investment in the form of dividends and capital gains. Investment theory states "high risk high return, low risk low return". Risk is a form of uncertainty about an investment. Uncertainty is intrinsically contained in every economic activity (Wild $\&$ Wild, 2012). The risks faced in every investment decision require investors to be careful and conduct careful analysis and consideration in making stock investments.

\subsection{Fundamental Analysis}

The prospect of the company depends on the overall economic situation. Stock valuation analysis must be considered several macroeconomic variables that affect a company's ability to generate profits. Top-down analysis can be done by investors in stock valuation to determine the company's prospects.

\subsubsection{Economic and Capital Market Analysis}

Economic analysis is carried out because of the tendency for a strong relationship between what happens in the macroeconomic environment and the performance of the capital market. The purpose of macroeconomic analysis is to make an allocation of funds investment decisions in the form of shares in several countries or in the country. The ability of investors to understand and forecast macroeconomic conditions is very useful in making investment decisions (Baresa et al., 2013). The macroeconomic variables that are worthy of analysis are Gross Domestic Product (GDP), Inflation, Rupiah exchange rate against the US dollar, and interest rates.

\subsubsection{Industrial Analysis}

Industrial analysis aims to compare the performance of various industries to find out the types of industries that provide the most promising prospects (Jones, 2013). Industrial analysis is important to minimize risks and identify industries that have profitable prospects. Assessing the industry can be done through two steps, namely first estimating expected earnings per share (EPS) from the industry and the second estimating the expected price earnings ratio (P / E) (Jones, 2013). The factor that influences the amount of profit obtained by an industry is the intensity of competition in the industry. The intensity of competition determines the ability of the industry to still obtain a rate of return above the average.

\subsubsection{Company Analysis}

Analysis of the company provides an overview of company value, internal characteristics, company quality, management performance, and future company prospects (Jones, 2013). The results of the analysis of company shares are then compared between intrinsic value and market value. Stocks are said to be undervalued and are worth buying if the market value is lower than the intrinsic value. Information on financial statements issued by companies is one of the easiest and cheapest types of information obtained in conducting company analysis. Information of financial statement is enough to describe the development of the condition of the company so that investors can calculate the amount of earnings growth that the company has achieved against the number of company shares (Baresa et al., 2013).

\subsection{Integration of Economic and World Capital Market}

The world economic and financial system is increasingly integrated with the expansion of international trade in commodities, services, and financial assets. The linkage between trade in commodities and services arises from the existence of export-import activities carried out by almost all countries, both regional and global. All countries try to remove trade barriers related to the flow of capital, goods and services. Policies to strengthen economic cooperation are carried out by eliminating discrimination, uniting policies related to various instruments, such as import duties, taxes, currency, laws, standardization so that global economic integration slowly occurs (Wild \& Wild, 2012). Integration of international trade triggers financial integration with an increasing trend (Tadaki et al., 2016). The dynamics of capital markets are one of the main indicators in changing the economy in the world (Putyinceva et al., 2016). According to Wild \& Wild (2012) the formation of economic integration has an impact on reducing the boundaries in the flow of products, labor, and capital on an international scale. In a cointegration relationship between capital markets there is a causal relationship where changes in one capital market will affect other capital markets or influence each other (Chia Liang et al., 2013). Integrated capital markets between countries have several advantages, including the increase of foreign investment which also increases the value of shares.

Based on the background, literature review, and previous research, the following hypotheses can be formulated: 
H1: Gross Domestic Product (GDP) has a significant positive effect on the Indonesian Of Composite Stock Prices Index.

$\mathrm{H} 2$ : The rupiah exchange rate against the US dollar has been positively to the Indonesian Of Composite Stock Price Index.

H3: Inflation has a significant negative effect on the Indonesian Of Composite Stock Price Index.

H4: Interest rates have a significant negative effect on the Indonesian Of Composite Stock Price Index.

H5: The Dow Jones Index has a significant positive effect on the Indonesian Of Composite Stock Price Index.

H6: The BSE Sensex Index has a significant positive effect on the Indonesian Of Composite Stock Price Index.

H7: The Nikkei_225 index has a significant positive effect on the Indonesian Of Composite Stock Price Index.

H8: The Shanghai Index has a significant positive effect on the Indonesian Of Composite Stock Price Index.

\section{Research Method}

This type of research is associative/explanatory research that aims to test the hypothesis of the influence of independent variables on the dependent variable. The independent variable in this study is Indonesian composite stock prices index. The independent variable consists of the Dow Jones index (American), the BSE Sensex index (India), the Nikkei_225 index (Japan), and the Shanghai (Chinese) index. The source of research data is secondary data obtained from www.finance. yahoo.com for Dow Jones index data, BSE Sensex index, Nikkei 225 index, Shanghai index. Gross Domestic Product Data obtained from www.bps.go.id. Data on IDR/ US exchange rates, inflation and interest rates are obtained from www.bi.go.id.

The population in this study is the Indonesian joint stock price index (CSPI). The method of collecting data is through a census by investigating population elements one by one. Data on Indonesia's macroeconomic indicators and global stock indices are taken quarterly for the 10-year period of 2010-2018.

\section{Results and Discussion}

\subsection{Results}

The test results using multiple linear regression analysis indicated that the test value simultaneously (Test F) was 39,560 with a significance of 0,000 . These results indicate that the regression model built can be used to predict the rise and fall of the JCI. The independent variables in this study have an effect simultaneously on the JCI.

Table 1. Statistical Test Results

\begin{tabular}{|c|c|c|c|c|c|c|}
\hline \multirow{2}{*}{\multicolumn{2}{|c|}{ Model }} & $\begin{array}{c}\text { Unstandardize } \\
\text { d Coefficients }\end{array}$ & $\begin{array}{c}\text { Standardized } \\
\text { Coefficients } \\
\end{array}$ & \multirow[b]{2}{*}{ T } & \multirow[b]{2}{*}{ Sig. } & \multirow[t]{2}{*}{ Information } \\
\hline & & Beta & Beta & & & \\
\hline \multirow[t]{9}{*}{1} & (Constant) & 1716.597 & & 1.262 & .218 & \multirow{3}{*}{$\begin{array}{l}\text { Significant positive } \\
\text { Significant positive }\end{array}$} \\
\hline & PDB & .003 & .995 & 2.933 & .007 & \\
\hline & Exchange rate & .306 & .705 & 2.318 & .028 & \\
\hline & Inflation & -74.222 & -.136 & -1.635 & .114 & No Significant \\
\hline & Interest rate & -45.473 & -.053 & -.468 & .644 & No Significant \\
\hline & Dow_lones & .154 & .741 & 1.740 & .009 & Significant positive \\
\hline & Nikkei_225 & -.009 & -.045 & -.123 & .043 & Significant negative \\
\hline & BSE_Sensex & -.020 & -.136 & -.605 & .550 & No Significant \\
\hline & Shanghai & .143 & .085 & .876 & .038 & Significant positive \\
\hline \multicolumn{5}{|c|}{ F Test } & 0.000 & \multirow[t]{2}{*}{ Simultaneous effed } \\
\hline \multicolumn{5}{|c|}{ Adjusted $\mathrm{R}^{2}$} & 0.960 & \\
\hline
\end{tabular}

Table 1. Shows that the variable GDP, Exchange Rate, Dow Jones Index, Nikkei_225 index, and Shanghai index have significance $\alpha<0.05$ and B coefficient shows the direction of the independent variable relationship with the index of the Indonesian joint stock price. Based on multiple linear regression analysis while the equations that can be built are as follows:

$\mathrm{Y}=1716,597+0,003$ GDP + 0,306 Exchange Rate - 74,222 Inflation - 45,473 Interest rate + 0,154 Dow Jones - 0,020 BSE Sensex - 0,009 Nikkei225 + 0,143 Shanghai + e

The coefficient of determination (R2) of 0.960 or $96.0 \%$ shows the variable GDP, Exchange Rate, Dow Jones Index, Nikkei_225 index, and the Shanghai index explains that IHSG changes of $96 \%$ and the remaining $4 \%$ were explained by other variables not included in this study. 


\subsection{Discussion}

\subsubsection{The Effect of Gross Domestic Product (GDP) on JCI}

GDP has a significant positive effect on the JCI. The higher the GDP value of Indonesia, the higher of composite stock prices index in Indonesia will also be higher. The relationship of the variable moves in the same direction. The results of this study were in line with the research conducted by Lee et al (2006); Acikalin et al (2008); Singh et al (2011); Jiangang et al (2013); Jareno \& Loredana (2016). The increasing number of consumer goods causes the economy to grow and increase the scale of the company's sales turnover, because people were consumptive. Increased sales turnover has an effect on increasing profits. The profits obtained by the company also increased so that it affected the JCI movement.

\subsubsection{The Effect of the rupiah / US dollar exchange rate on the JCI}

The Exchange Rate of Rupiah / US Dollar has a significant positive effect on the JCI. The higher the Exchange Rate of Rupiah / US Dollar Indonesia, Indonesian composite stock price index will also be higher, and vice versa. The relationship of the variable moves in the same direction. The results of this study were supported by Acikalin et al (2008); Geetha et al (2011); Tangjitprom (2012); Chia Liang et al (2013); Dar et al (2014); Alam \& Kashif (2014); Oktarini (2016); Jamaludin (2017); Balagobei, (2017). The strengthening of the rupiah exchange rate against foreign currencies will reduce the cost of importing raw materials and reduce the prevailing interest rates. The company will get a bigger profit by exporting industrial products because of the increase in the value of the rupiah. This condition will encourage an increase in profits earned by the company so that it will automatically increase stock prices.

\subsubsection{The Effect of inflation on the JCI}

Inflation has a negative but not significant effect on the JCI. Changes in inflation value did not significantly change the JCI value. The relationship of the variable moves unidirectio nally. The general increase in prices of goods will have an impact on the decline in public consumption due to a decline in real income. Ozbay (2009) research results; Singh et al (2011); Greeta et al (2011); Chia Liang et al (2013); Alam \& Kashif (2014); Ahmad \& Ramzan (2016); Jamaludin et al (2017); indicates that inflation has a negative effect on the composite stock prices index. The decline in people's purchasing power was detrimental to producers which causes a decrease in the company's production level. If the increase in production costs was higher than the price increase that can be enjoyed by the company, the company's profitability will decrease.

\subsubsection{The Effect of interest rates on the JCI}

Interest rates have a negative but not significant effect on the JCI. Changes in interest rates did not significantly change the JCI value. The relationship of the variable moves unidirectionally. Amarasinghe research results (2015); Vuong (2015); Wahyudi et al., (2017); Yin et al., (2017); Khan \& Imran (2018) show that interest rates negatively affect the stock price index. When interest rates rise, the operating costs will also increase, thereby reducing the profitability of the company to make a profit. This condition did not provide prospects for investors in placing their funds in the capital market, consequently the stock price will decline.

\subsubsection{The Effect of the Dow Jones index on the JCI}

The Dow Jones index has a significant positive effect on the JCI. The relationship of the variable moves in the same direction. America was the second export destination after China. Indonesia-America's total trade in the last 5 years (2014-2018) recorded growth of 3.84\% (Ministry of Trade, 2018). The total trade value in 2018 was 28,602,881.7 thousand US Dollars. The condition of the American economy was reflected through the Dow Jones index. Research results of Khajar et al (2015); Murti, 2017; Deitiana \& Stela, 2009; Kartika et al (2012) showed that the Dow Jones Index had a positive and significant effect on the JCI.

\subsubsection{The Effect of Sensex BSE index on JCI}

BSE Sensex Index has a negative but not significant effect on the JCI. Changes in the BSE Sensex Index did not significantly change the JCI value. The relationship of the variable moves unidirectionally. The results of this study were in line with the results of research conducted in Asia by Horta et al, 2014 and Khajar, 2015 that the BSE Sensex index has an effect on the JCI. The results study of Kumar \& Puja (2012) and Nisha (2017) state that the conditions of Indian macroeconomic fundamentals influence the Sensex BSE index according to the characteristics of the variable itself. The total trade between Indonesia and India over the past 5 years (20142018) recorded a growth of 5.31\% (Ministry of Trade, 2018). The total trade value for 2018 was 18,742,588 thousand US Dollars. Indonesia's level of dependence on India was still quite low considering that export growth was smaller than imports so that if there was a turmoil on the Indian economy then Indonesia will not be significantly affected.

\subsubsection{The Effect of the Nikkei 225 index on the JCI}

The Nikkei-225 index has a negative and significant influence on the JCI. The relationship of the variable moves undirectionally. Changes in the Nikkei_225 index deserve consideration for investors to predict the condition of the JCI. The total trade between Indonesia and Japan over the past 5 years (2014-2018) recorded growth of $0.82 \%$ (Ministry of Trade, 2018). The total trade value in 2018 was 37,456,603.5 thousand US Dollars. Indonesia's level of dependence on Japan was still relatively high considering that export growth was smaller 
than imports so that if there was turmoil in the Japanese economy, Indonesia will be affected in the opposite direction. The results of the research by Harbi et al (2016); Oktariani (2016); Deitiana \& Stela, 2009; Kusumawati \& Nadia, 2017 showed the effect of the Nikkei 225 stock index, which negatively affected the JCI.

4.2.8 The Effect of the Shanghai index on the JCI

The Shanghai index has a positive and significant influence on the JCI. The relationship of the variable moves in the same direction. The total trade between Indonesia and China over the past 5 years (2014-2018) recorded growth of $11.63 \%$ (Ministry of Trade, 2018). The total trade value for 2018 is $72,664,763.1$ thousand US Dollars. Indonesia's level of dependence on China was very high and Indonesia' was the main trading partner of China. The turmoil that occurred in China greatly influenced the economic condition of Indonesia which was proxied by the JCI. The results of this study were in line with the results of research conducted by (Sidiq, 2010; Khajar, 2015; Harbi et al., 2016; Murti, 2017).

\section{Conclusion}

The research model that was built was able to explain $96 \%$ related to the rise and fall of the IHSG and the remainder was explained by other variables not included in this study. Independent variables that were worthy of being taken into consideration for investors to purchase shares on the Indonesia Stock Exchange were Gross Domestic Product (GDP), the exchange rate of Rupiah / US dollar, Dow Jones index, Nikkei-225 index, and the Shanghai index. These variables significantly affect the movement of the JCI.

\section{References}

Acikalin, Sezgin., Rafet Aktas, \& Seyfettin Unal.2008. Relationships between stock markets and macroeconomic variables: an empirical analysis of the Istanbul Stock Exchange. Investment Management and Financial Innovations, Volume 5, Issue 1, 2008

Ahmad, Naveed \& Muhammad Ram zan. 2016. Stock Market Volatility and Macroeconomic Factor Volatility. International Journal of Research in Business Studies and Management Volume 3, Issue 7, July 2016, 37-44

Alam, Zaheer \& Kashif Rashid. 2014. Time Series Analysis of the Relationship between Macroe conomic Factors and the Stock Market Returns in Pakistan. Journal of Yasar University, 2014 9(36) 6261 - 6380

Balagobei, Saseela. 2017. Macroecon omic Variables and Stock Market Returns in Sri Lanka. Asian Journal of Finance \& Accounting ISSN 1946-052X 2017, Vol. 9, No. 2

Baresa, Suzana., Sinisa Bogdan., \& Zoran Ivanovic. 2013. Strategy of stock valuation by fundamental analysis. Special issue, UTMS Journal of Economics 4 (1): 45-51.

Chia Liang, Chin., Jeng-Bau Lin, \& Hao-Cheng Hsu.2013. Reexami ning the relationships between stock prices and exchange rates in ASEAN-5 using panel Granger causality approach. Economic Modelling 32 (2013) $560-563$

Dar, Arif Billah., Aasif Shah., Niyati Bhanja., \& Amaresh Samantara ya. 2014. The relationship between stock prices and exchange rates in Asian markets: A wavelet based correlation and quantile regression approach. Emerald Insight Journal.

Devika. P \& S. Poornima.2015. Fundamental Analysis as a Meth od of Share Valuation in Comparison with Technical Analysis. Journal of Exclusive Management Science - December 2015 - Vol 4 Issue 12 - ISSN $2277-5684$

Geetha, Caroline., Rosle Mohidin., Vivin Vincent Chandran,., Victoria Chong. 2011. The Relationship Between Inflation And Stock Market: Evidence from Malaysia, United States and China. International Journal Of Economics and Management Sciences Vol 1, No 2, 2011,pp.01-16

Jamaludin, Nurasyikin., Shahnaz Ismail., \& Syamimi Ab Manaf. 2017. Macroeconomic Variables and Stock Market Returns: Panel Analysis from Selected ASEAN Countries.. International Journal of Economics and Financial Issues, 2017, 7(1), 37-45.

Jareño, Francisco \& Loredana Negrut. 2016. US Stock Market and Macroeconomic Factors. The Journal of Applied Business Research - January/February 2016 Volume 32, Number 1

Jones, Charles P. 2013. Investments Principles and Concepts. Singa pore: Kenji Ngieng.

Khadjar, Ibnu.2015. The Global Stock Exchange And Its Influence Toward The Indonesia Stock Exchange After The Global Financial Crisis In 2008. The International Journal of Organizational Innovation Vol 8 Num 1 July 2015

Kumar, Naik Pramod and Padhi Puja. 2012. The impact of Macro economic Fundamentals on Stock Prices revisited: An Evidence from Indian Data.

Lee, Minsoo., Hua Hwa Au Yong., \& Jun Zhang. 2006. Macroeconomic Variables and Stock Market Interactions: New Zealand Evidence. Artikel (tidak diterbi tkan). Investment Management and Financial Innovations, Volume 3, Issue 4, 2006

Mark, Boon Leng.2017. A Singaporean Study on Macroeconomic Variables Impacting Stock Returns. Asian Journal of Finance \& Accounting Vol. 9, No. 2 
Mark, Boon Leng.2017. A Singaporean Study on Macroeconomic Varia bles Impacting Stock Returns. Artikel (tidak diterbitkan). Asian Journal of Finance \& Accounting Vol. 9, No. 2

Murti, Wahyu. 2017. The Effects of Gold Prices, the Hang Seng Index, and the Dow Jones Index on the Composite Stock Price Index (CSPI) in Indonesia. Artikel (tidak diterbitkan). International Journal of Economic Perspectives, 2017, Volume 11, Issue 2, 258-266

Ozbay, Emrah. 2009. The Relationship Between Stock Returns And Macroeconomic Factors: Evidence From Turkey. Financial Analysis And Fund Management University Of Exeter September 2009.

Putyinceva, Kszénia \& Hauke Steffe n.2016. Influence of Macroecono mic Factors on the Performance of Sector Stock Indices.

Singh, Narinder Pal \& Sugandha Sharma. 2018. Phase-wise analysis of dynamic relationship among gold, crude oil, US dollar and stock market. Artikel (tidak diterbitkan). Emerald Insight Journal.

Tadaki, Komatsubara; Okimoto Tatsu yoshi; \& Tatsumi Ken-ichi. 2016. Dynamics of Integration in East Asian Equity Markets. RIETI Discussion Paper Series 16-E-084

Tarigan, Razaq Dastanta, Suhadak, Topowijoyo.2015. Pengaruh inde ks harga saham global terhadap indek harga saham gabungan (IHSG) studi pada Bursa Efek Indonesia (BEI) periode 2011-2014. Artikel (tidak diterbitkan).

Vuong, Quoc Duy \& Le Long Hau. 2017. Impact of Macroeconomic Factors on Share Price Index in Vietnam's Stock Market. Artikel (tidak diterbitkan). The Interna tional Journal Of Engineering And Science (IJES)

Wild, J. J., \& Wild, K. L. 2012. Internati onal Business : The Challenges of Globalization Sixth Edition. Harlow, England: Pearson Education Limited. 